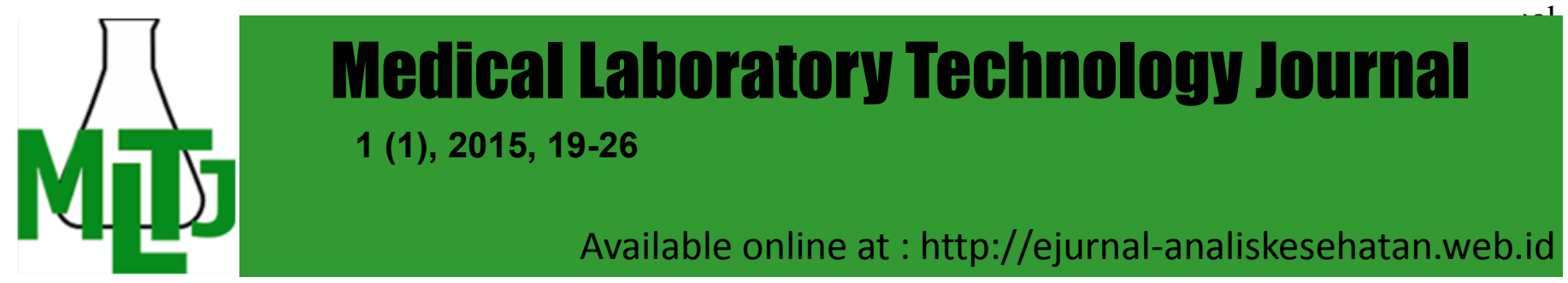

\title{
KULIT PISANG KEPOK (Musa paradisiaca L.) UNTUK MENURUNKAN KADAR MANGAN AIR SUMUR
}

\author{
Anny Thuraidah, Jasmadi Joko Kartiko, Lailan Febry Ariani \\ Jurusan Analis Kesehatan Poltekkes Kemenkes Banjarmasin \\ JI Mistar Cokrokusumo 4a Banjarbaru \\ e-mail: Annythura2014@gmail.com
}

\begin{abstract}
Water is an essential requirement. Part of Indonesian people still using well as the source of water Resulting from the increased of human activity and industries, the well water maybe contaminated by manganese $(\mathrm{Mn})$. That is needed processing to make well water usefull for mankind. One of the type for processing water is the absorbtion methode .Banana shell was kitchen waste and the dried of Kepok Banana (Musa paradisiaca) Shell was used as adsobent to reduce Manganese level in water. This study aimed to determine the reduce of Manganese level in water. This research was real experiment pretest and posttest study design with a control group. Persulfate research instruments colorimetric and spectrophotometric measurements. The addition of the dose banana shell were 0,$06 ; 0,07 ; 0,08 ; 0,09 ; 0,1 \mathrm{gram}$. By those dose cumulatively decreased to $0 ; 21,84 ; 32,34 ; 44,56$; and $52,92 \%$. The Manganese maximum reduced by 0,1 gram dried banana shell in $100 \mathrm{cc}$ well water in 30 minutes. Stastically, the significan value was 0,000 less than $0,05(\alpha)$, it was meant that the variety dose of dried Kepok banana shell influence to decrease Manganese level in water. These decreased way can be used as an alternative to increase the water quality.
\end{abstract}

Keywords: manganese, kepok banana shell

Abstrak: Air merupakan kebutuhan utama bagi masyarakat Indonesia. Sumber air yang banyak digunakan adalah air tanah, yaitu air sumur. Diakibatkan dari meningkatnya aktivitas manusia dan industri, air sumur dapat tercemar mangan (Mn). Untuk dapat menjadikan air sumur sebagai sumber air bersih, perlu dilakukan pengolahan. Proses pengolahan ini dapat dilakukan dengan metode adsorpsi. Bahan yang dipakai dapat dimanfaatkan dari limbah dapur rumah tangga seperti kulit pisang kepok (Musa paradisiaca L.) sebagai bahan adsorben. Penelitian bertujuan untuk mengetahui penurunan kadar mangan dalam air dengan menggunakan kulit pisang kepok (Musa paradisiaca L.) yang dikeringkan. Penelitian ini berjenis eksperimen sebenarnya rancangan penelitian Pretest dan Posttest dengan Kelompok Kontrol. Instrumen penelitian persulfat kolorimetri dan pengukuran secara spektrofotometri. Secara kumulatif penurunan kadar mangan dari hasil penambahan kulit pisang kepok dengan dosis 0 gram, 0,06 gram, 0,07 gram, 0,08 gram, 0,09 gram, dan 0,1 gram berturut-turut adalah sebesar $0 \%, 21,845 \%, 32,637 \%, 37,337 \%, 44,560 \%$, dan 52,916\%. Hasil maksimum dari reaksi tersebut yaitu kadar mangan dalam air berkurang hingga $52,916 \%$ untuk dosis $0,1 \mathrm{gram} / 100$ $\mathrm{ml}$ air selama 30 menit. Pada hasil statistik didapatkan nilai signifikasi $p=0,000(\alpha 0,05)$ atau ada pengaruh dosis kulit pisang kepok terhadap penurunan kadar mangan pada air sumur. Penurunan kadar mangan melalui cara ini dapat dijadikan alternatif untuk mendapatkan air bersih dari air sumur.

Kata kunci: Mangan (Mn), Kulit Pisang Kepok 


\section{PENDAHULUAN}

Air merupakan sumber daya alam yang diperlukan untuk hajat hidup orang banyak, bahkan oleh semua makhluk hidup. Oleh karena itu, sumber daya air harus dilindungi agar tetap aman dan dimanfaatkan dengan baik oleh manusia serta makhluk hidup yang lain (Effendi, 2003).

Sumber air ada bermacam-macam, diantaranya yaitu air permukaan, air hujan, dan air tanah. Masyarakat di Indonesia banyak yang menggunakan sumur gali untuk memenuhi kebutuhan akan air bersih. Namun tidak menutup kemungkinan bahwa air yang terdapat dalam sumur gali mengandung bahan pencemar organik maupun anorganik. Berdasarkan penelitian dari Purwanto tahun 2005, didapatkan bahwa sebanyak $33 \%$ sumur di daerah Jakarta mengandung mangan dengan kadar yang melebihi baku mutunya (Effendi, 2003). Penelitian selanjutnya yang dilakukan oleh Ashar tahun 2007, ditemukan bahwa kandungan mangan yang cukup tinggi terdapat di sumur gali yang dekat dengan TPA (Tempat Pembuangan Akhir), dalam hal ini adalah TPA Rawakucing yang berlokasi di Kecamatan Neglasari, Kota Tangerang, Banten. Rata-rata kadar mangan yang terdapat pada sumur gali di sekitar daerah tersebut adalah sebesar 4,3 $\mathrm{mg} / \mathrm{L}$. Kadar mangan tersebut lebih besar dibanding dengan kadar mangan yang terdapat pada air sumur di luar TPA.

Kadar mangan yang cukup tinggi juga terdapat pada sumur di daerah Banjarbaru. Pada bulan Februari 2014 ini peneliti melakukan pemeriksaan kadar mangan pada air sumur di daerah Banjarbaru. Peneliti mengumpulkan 3 sampel air sumur dari 3 lokasi berbeda. Setelah dilakukan uji kandungan Mn dan dengan menggunakan kurva baku mangan, didapatkan bahwa dari ketiga sampel tersebut mengandung mangan cukup tinggi, yaitu pada sampel 1 sebesar 0,736 ppm; sampel 2 sebesar 0,685 ppm; dan sampel 3 sebesar 0,722 ppm.

Mangan (Mn) sebenarnya merupakan mikronutrien esensial bagi semua makhluk hidup. Namun, dalam dosis yang tinggi mangan dapat membahayakan tubuh. Mangan dapat mengakibatkan toksisitas pada sistem syaraf pusat (Widowati et al., 2008). Berdasarkan data pada tahun 2010 dari CINBIOSE (Center for Interdisciplinary Research in Biology, Health, Enviroment and Society), Universitas du Qu bec-Montr-al, Amerika Utara, yang dilansir oleh Child Health News, dikatakan bahwa konsumsi mangan dengan konsentrasi tinggi pada air minum dapat menyebabkan penurunan kecerdasan (IQ) pada anak. Selain itu mangan yang mengalami presipitasi dapat menyebabkan air berwarna coklat dan keruh. Oleh karena itulah air tanah yang mengandung mangan sebaiknya diolah terlebih dahulu sebelum dikonsumsi sehingga memenuhi persyaratan sesuai Peraturan Menteri Kesehatan RI No. 416/MENKES/PER/IX/1990 tentang syarat-syarat dalam pengawasan kualitas air bersih, syarat kadar maksimum Mn yang diperbolehkan untuk air bersih adalah sebesar 0,5 $\mathrm{mg} / \mathrm{L}$. Berbagai usaha dapat dilakukan untuk menanggulangi pencemaran logam antara lain menggunakan metode fitoremediasi, pengolahan dengan proses fisika, kimia, dan filtrasi serta teknologi pengendapan. Untuk mengurangi pencemaran $\mathrm{Mn}$, bisa digunakan Manganese Zeolit atau Rhizospora mucronta sebagai bioakumulator Mn (Widowati et al., 2008).

Baru-baru ini ditemukan inovasi mengenai pemanfaatan kulit pisang sebagai media adsorben dalam penurunan kadar logam dalam air. Penelitian yang dilakukan oleh Aryani tahun 2013 menemukan bahwa kulit pisang kepok (Musa acuminate) dapat menurunkan kadar $\mathrm{Fe}^{2+}$ dalam air sebanyak $11,20 \%$ dengan konsentrasi kulit pisang sebesar $10 \%$.

Pemanfaatan kulit pisang sebagai adsorben logam tidak banyak diketahui oleh masyarakat. Selama ini kita ketahui bahwa pisang memiliki banyak manfaat mulai dari bonggol pisang hingga batang pisang. Namun untuk kulit pisang yang telah lepas dari buahnya akan langsung dibuang begitu saja dan menjadi limbah. Berdasarkan fakta tersebut maka banyak penelitian yang didasarkan pada gagasan untuk mengolah limbah kulit pisang menjadi sesuatu yang bermanfaat bagi masyarakat luas, salah satunya adalah pemanfaatan kulit pisang dalam menurunkan kadar logam pada air sebagai upaya meningkatkan kualitas air.

Menurut Dirjen Hortikultura tahun 2006, Kalimantan Selatan merupakan salah satu sentra produksi pisang terutama pisang kepok. Efektivitas dari kulit pisang kepok dalam proses adsorbsi jauh lebih baik dibanding dengan karbon dan silika. Kulit pisang kepok ini dapat digunakan berkali-kali hingga 11 kali proses adsorpsi logam. Gugus karboksil dan kadar selulosa hidroksil akan langsung mempengaruhi penjerapan logam $\mathrm{Cu}$ dan $\mathrm{Pb}$ (Castro, 2011). 
Berdasarkan latar belakang diatas maka peneliti ingin melakukan penelitian dengan menggunakan kulit pisang kepok untuk menurunkan kadar Mangan dalam air sebagai upaya meningkatkan kualitas air. Tujuan penelitian ini adalah untuk mengetahui pengaruh penambahan kulit pisang kepok (Musa paradisiaca L.) terhadap pengolahan sampel air sumur dalam menurunkan kadar mangan.

\section{BAHAN DAN METODE}

Penelitian ini merupakan penelitian eksperimen sebenarnya (True eksperiment) dengan bentuk rancangan penelitian Pretest dan Posttest dengan Kelompok Kontrol (Pretest and Posttest With Control Group) (Notoatmodjo, 2010). Pretest dilakukan dengan menggunakan sampel air sumur tanpa perlakuan. Kelompok kontrol dalam penelitian ini berupa akuades $100 \mathrm{ml}$ sebagai kontrol negatif dan $100 \mathrm{ml}$ larutan standar Mn 5 ppm sebagai kontrol positif.

Bahan penelitian yang digunakan pada penelitian ini adalah kulit pisang kepok (Musa paradisiaca L.) dan air sumur yang terdapat di gang Astoria, Banjarbaru.

Variabel bebas dalam penelitian ini adalah kulit pisang kepok (Musa paradisiaca L.) dengan dosis 0 gram; 0,06 gram; 0,07 gram; 0,08 gram; 0,09 gram; dan 0,1 gram dalam $100 \mathrm{ml}$ air sumur. Variabel terikat dalam penelitian ini adalah kadar Mangan $(\mathrm{Mn})$ dalam air sumur.

Bahan penelitian diambil dengan teknik purposive sampling, yaitu sesuai dengan kriteria yang ditentukan berupa kulit pisang kepok yang berwarna kuning bersih yang terdapat di Banjarbaru. Uji determinasi pada tanaman pisang kepok dengan melakukan uji determinasi di Laboratorium Dasar FMIPA Universitas Lambung Mangkurat.

Pembuatan pereaksi khusus: Dilarutkan 75 gram $\mathrm{HgSO}_{4}$ dalam $400 \mathrm{ml} \mathrm{HNO}_{3}$ pekat. Ditambahkan $200 \mathrm{ml} \mathrm{HNO}_{3}$ pekat $85 \%$ dan 0,03 gram $\mathrm{AgNO}_{3}$. Dilarutkan dan diencerkan sampai 1 liter.

Pembuatan kurva baku: Dibuat larutan baku (standar) dan standar induk dengan konsentrasi bertingkat $(0,2 \mathrm{ppm} ; 0,4 \mathrm{ppm} ; 0,6$ ppm; 0,8 ppm; dan 1,0 ppm) dalam $100 \mathrm{ml}$ akuades di dalam erlenmeyer. Ditambahkan 5 $\mathrm{ml}$ pereaksi khusus. Dipanaskan dan didihkan selama 5 menit. Diangkat dan ditambahkan masing-masing 1 gram (sepucuk sendok) am- monium persulfat/ Kalium persulfat. Dididihkan kembali selama 5 menit. Warna ungu kemerahan yang terbentuk menunjukkan adanya kandungan mangan. Didinginkan pada suhu kamar. Dipindahkan secara kuantitatif ke dalam labu ukur $100 \mathrm{ml}$, lalu diencerkan sampai tanda batas. Dikocok sampai tercampur rata. Ditentukan kadarnya dengan spektrofotometer dengan panjang gelombang $525 \mathrm{~nm}$.

Persiapan sampel: Menyiapkan sampel air sumur yang di perkaya dengan mangan sehingga kadar mangan pada air sumur menjadi 1,149 ppm.

Persiapan kulit pisang kepok: Kulit pisang kepok diambil dari buahnya kemudian dicuci sampai bersih. Kulit pisang kepok lalu di potong kecil. Kulit pisang kepok di keringkan dalam oven dengan suhu $100^{\circ} \mathrm{C}$ selama 1 jam. Kulit pisang kepok lalu di timbang konstan dengan neraca analitik elektrik. Kulit pisang kepok siap digunakan untuk percobaan.

Perlakuan sampel air sumur dengan penambahan kulit pisang kepok: Sampel air sumur dengan kadar mangan 1,149 ppm, diberikan 6 perlakuan dengan masing-masing 4 kali pengulangan, sehingga seluruh sampel berjumlah 24 dengan perlakuan sebagai berikut: Disiapkan semua alat dan bahan yang akan digunakan. Disiapkan $100 \mathrm{ml}$ sampel air sumur yang telah diketahui kadar mangannya masingmasing ke dalam 6 buah beaker glass. Kemudian ditambahkan kulit pisang kapok masing-masing 0 gram; 0,06 gram;0,07 gram; 0,08 gram; 0,09 gram, dan 0,1 gram.Direndam selama 30 menit. Disaring menggunakan kertas saring. Dipindahkan ke dalam erlenmeyer.

Pemeriksaan kadar Mangan (Mn) setelah penambahan kulit pisang kepok: Sampel air sumur yang telah diberi perlakuan dan siap diperiksa dicampur merata. Dipindahkan ke dalam erlenmeyer. Ditambah $5 \mathrm{ml}$ pereaksi khusus. Dipanaskan dan didihkan selama 5 menit. Diangkat dan ditambahkan masingmasing 1 gram (sepucuk sendok) Ammonium persulfat/ Kalium persulfat. Dididihkan kembali selama 5 menit. Warna ungu kemerahan yang terbentuk menunjukkan adanya kandungan mangan. Didinginkan pada suhu kamar. Dipindahkan secara kuantitatif ke dalam labu ukur $100 \mathrm{ml}$, diencerkan sampai tanda batas. Dikocok sampai tercampur rata. Ditentukan 
kadarnya dengan spektrofotometer dengan panjang gelombang $525 \mathrm{~nm}$.

Perhitungan terlebih dahulu dibuat tabel dan grafik kurva baku yang diambil dari hasil pengukuran kurva baku dengan konsentrasi standar 0,0 ppm; 0,2 ppm; 0,4 ppm; 0,6 ppm; 0,8 ppm; dan 1,0 ppm untuk mengetahui nilai absorbansi standar nya. Kemudian dibuat kurva larutan baku mangan menggunakan Microsoft Excel 2010 dan dilakukan perhitungan untuk mencari absorbansi standar dengan dasar sebagai berikut:

$y=b x+a$

Keterangan :

$\mathrm{y}=$ Absorbansi sampel

$\mathrm{a}=$ diketahui pada kurva baku

$\mathrm{b}=$ diketahui pada kurva baku

$\mathrm{x}=$ Absorbansi standar

Dari tabel serta grafik yang dibuat, kita dapat mengetahui absorbansi standar dari hasil pengukuran kadar mangan pada sampel air sumur yang kemudian akan dimasukkan ke dalam rumus perhitungan kadar mangan secara spektrofotometri.

Rumus:

$\mathrm{mg} / \mathrm{L} \mathrm{Mn}=$ Abs. Sampel $\mathrm{x}$ Konsentrasi Standar Abs. Standar

Pada penelitian ini menggunakan lebih dari 2 kali perlakuan, yaitu sebanyak 6 kali perlakuan dengan skala ukur ratio sehingga analisa dari data penelitian ini dilakukan secara statistik dengan menggunakan uji regresi linier untuk melihat adanya pengaruh variabel bebas terhadap variabel terikat.

Kelemahan dalam penelitian ini adalah sampel yang digunakan untuk penelitian adalah sampel air sumur sehingga memungkinkan adanya faktor-faktor pengganggu seperti zat-zat lain yaitu $\mathrm{Fe}, \mathrm{Cd}, \mathrm{Cu}, \mathrm{Zn}$, dan $\mathrm{Cr}$ yang terkandung dalam air sumur dan kemungkinan dapat mempengaruhi hasil penelitian.

\section{HASIL DAN PEMBAHASAN}

Penelitian penurunan kadar mangan $(\mathrm{Mn})$ pada sampel air sumur dengan kulit pisang kepok (Musa paradisiaca L.) menggunakan sampel air sumur yang berada di gang Astoria, Banjarbaru, Kalimantan Selatan. Sampel air sumur tersebut dipilih oleh peneliti karena didukung oleh faktor air yang agak berbau dan terletak di dekat TPS warga sekitar. Air sumur juga masih dijadikan sumber air bagi warga yang bermukim di sekitar lokasi sumur tersebut, baik digunakan sebagai air untuk mencuci maupun sebagai air olahan untuk di konsumsi. Berdasarkan teori, kandungan logam yang besar pada air tanah/air sumur salah satu penyebabnya adalah karena sumur terletak berdekatan dengan TPS yang dapat menyebabkan pencemaran air yaitu mengandung logam berat salah satunya mangan (Mn).

Mangan merupakan salah satu logam berat yang berpotensi besar dalam membahayakan kesehatan tubuh manusia. Selain itu mangan juga dapat menyebabkan pencemaran lingkungan yaitu endapan koloid yang menempel atau tertinggal dalam sistem perpipaan, menyebabkan noda pada cucian pakaian, penyumbatan pada pipa distribusi, serta dapat menimbulkan warna dan bau yang tidak enak pada air.

Karena logam mangan memiliki bahaya yang besar pada kesehatan tubuh dan lingkungan, maka banyak penelitian mengenai penanggulangan mangan dengan menurunkan kadar mangan pada air. Salah satunya adalah menggunakan kulit pisang kepok (Musa paradisiaca L.).

Berdasarkan hasil penelitian dari Suprapti (2005), kulit pisang mengandung karbohidrat sebesar $18,5 \%$. Selain itu berdasarkan penelitian Castro (2012), kulit pisang terdiri dari sejumlah nitrogen, sulfur dan komponen organik seperti asam karboksilat, selulosa, hemiselulosa, pigmen klorofil, dan zat pektin yang mengandung asam galacturonic, arabinosa, galaktosa, dan rhamnosa.

Pemeriksaan ini dilakukan di Laboratorium Kimia Jurusan Analis Kesehatan. Sampel air yang digunakan dalam penelitian ini adalah sampel air sumur dengan kadar yang telah diketahui yaitu 1,149 ppm. Penelitian penurunan kadar $\mathrm{Mn}$ ini menggunakan kulit pisang kepok yang dikeringkan dengan cara pemanasan pada suhu $100^{\circ} \mathrm{C}$ selama 1 jam. Pemanasan $100^{\circ} \mathrm{C}$ dengan lama pemanasan 1 jam bertujuan untuk menghilangkan getah pada kulit pisang dan meningkatkan porositas dinding sel adsorpsi semakin besar. Luas permukaan yang besar diharapkan akan mengakibatkan 
besarnya kapasitas adsorpsi logam mangan (Mn). Pemilihan suhu $100^{\circ} \mathrm{C}$ selama 1 jam karena pada suhu yang terlalu tinggi akan mengakibatkan kerusakan permukaan struktur sel adsorben. Menurut Cavalcante et al., 2005, pemanasan dengan suhu tinggi yaitu lebih dari $105^{\circ} \mathrm{C}$ akan mengakibatkan penyusutan volume, penutupan pori-pori adsorben sehingga akan mengurangi kapasitas adsorpsi adsorben terhadap logam.

Kulit pisang kepok yang digunakan dalam penelitian ini diperoleh di daerah Banjarbaru. Kulit pisang kepok yang digunakan adalah bagian kulitnya yang telah dipisahkan dari seratnya di bagian dalam. Jumlah kulit pisang kepok yang ditambahkan kedalam $100 \mathrm{ml}$ sampel air sumur adalah sebanyak 0 gram; 0,06 gram; 0,07 gram; 0,08 gram; 0,09 gram; dan 0,1 gram. Sebelum penambahan kulit pisang kepok, terlebih dahulu sampel air sumur dengan kadar 1,149 ppm ditambahkan kulit pisang kepok ke dalam sampel dengan variasi dosis. Kulit pisang lalu direndam ke dalam sampel air sumur selama 30 menit perendaman. Setiap perlakuan yang ditambahkan kulit pisang kepok dilakukan pengulangan pengerjaan sebanyak 4 kali.

Penetapan kadar mangan pada penelitian ini menggunakan metode Persulfat Kolorimetri dan diukur secara spektrofotometri pada panjang gelombang $525 \mathrm{~nm}$. Kadar mangan ditentukan dengan mengkonversikan absorbansi sampel pada kurva standar.

Kurva standar yang diperoleh pada penelitian ini ditunjukkan pada gambar 2 :

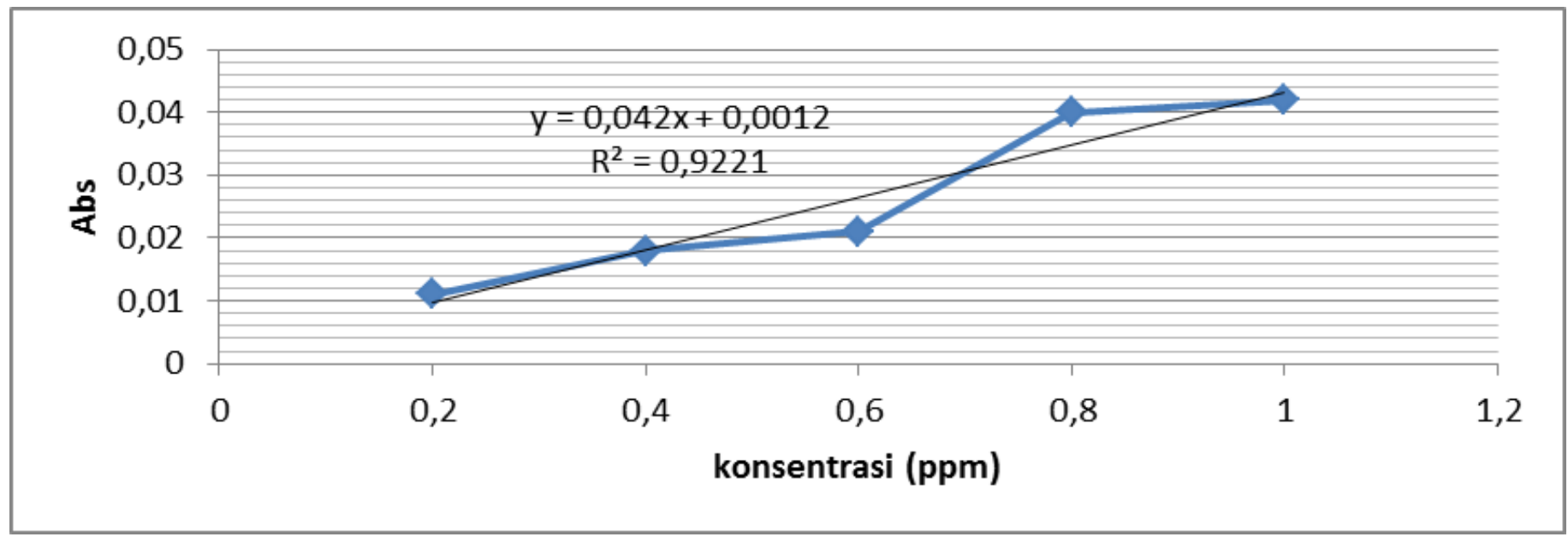

Gambar 2 Kurva kalibrasi larutan standar mangan

\section{Hasil Pemeriksaan Kadar Mangan}

Tabel 1 Hasil Variasi Perlakuan

\begin{tabular}{|c|c|c|c|c|c|c|}
\hline \multirow[b]{2}{*}{ Pengulangan Perlakuan } & \multicolumn{6}{|c|}{ Perlakuan dengan kulit pisang kepok } \\
\hline & $0 \mathrm{~g} / 100 \mathrm{ml}$ & $\begin{array}{ll}0,06 & \mathrm{~g} / 100 \\
\mathrm{ml} & \end{array}$ & $\begin{array}{|ll|}\begin{array}{l}0,07 \\
\mathrm{ml}\end{array} & \mathrm{g} / 100 \\
\end{array}$ & $\begin{array}{|ll|}0,08 & \mathrm{~g} / 100 \\
\mathrm{ml} & \\
\end{array}$ & $\begin{array}{ll}0,09 & \mathrm{~g} / 100 \\
\mathrm{ml}\end{array}$ & $0,1 \mathrm{~g} / 100 \mathrm{ml}$ \\
\hline $\begin{array}{l}\text { Pengulangan } 1 \\
(\mathrm{ppm})\end{array}$ & 1,143 & 0,904 & 0,809 & 0,714 & 0,643 & 0,547 \\
\hline Pengulangan 2 & 1,166 & 0,904 & 0,762 & $\overline{0,714}$ & $\overline{0,643}$ & 0,547 \\
\hline 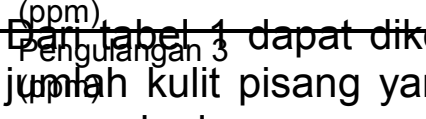 & 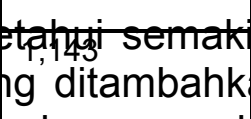 & $\begin{array}{l}\text { n, bब्मmyak } \\
\text { an, penu- }\end{array}$ & $\begin{array}{l}\text { Ga,jphbar pr } \\
\text { sampel air s }\end{array}$ & $\begin{array}{l}\text { Thuntant } k \\
\text { umur yang }\end{array}$ & 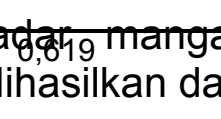 & $\begin{array}{l}\text { no,5dzatam } \\
\text { pat dilihat }\end{array}$ \\
\hline $\begin{array}{l}\text { retagulangandar mangan } \\
(\mathrm{ppm})\end{array}$ & at, & in, & 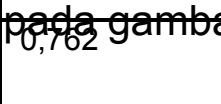 & 40,738 & 0,643 & 0,547 \\
\hline$\overline{\text { Rata-rata }(\mathrm{ppm})}$ & 1,149 & 0,898 & 0,774 & 0,720 & 0,637 & 0,541 \\
\hline
\end{tabular}

Dari tabel 1 dapat diketahui semakin banyak jumlah kulit pisang yang ditambahkan, penurunan kadar mangan akan semakin tinggi. Gambar penurunan kadar mangan dalam sampel air sumur yang dihasilkan dapat dilihat pada gambar 3 : 
Medical Laboratory Technology Journal

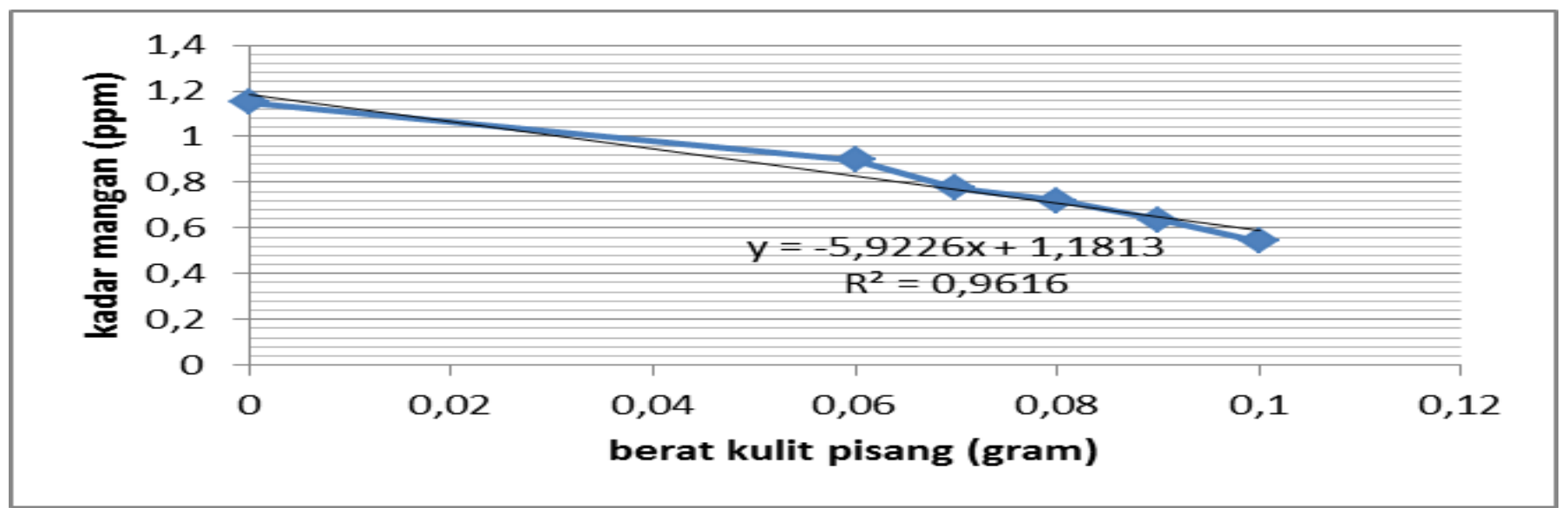

Gambar 3 Grafik pengaruh berat kulit pisang kepok terhadap kadar mangan

Dari grafik dapat dilihat persamaan garis regresi $y=-5,922 x+1,181$ dan $R^{2}=0,961$. Kadar mangan pada sampel air sumur semula yaitu 1,149 ppm mengalami penurunan, pada penambahan konsentrasi kulit pisang kepok sebanyak 0,1 gram terjadi penurunan menjadi
$0,541 \mathrm{ppm}$.

Grafik persentase penurunan kadar mangan $(\mathrm{Mn})$ dengan penambahan beberapa konsentrasi kulit pisang kepok dapat dilihat pada gambar 4:

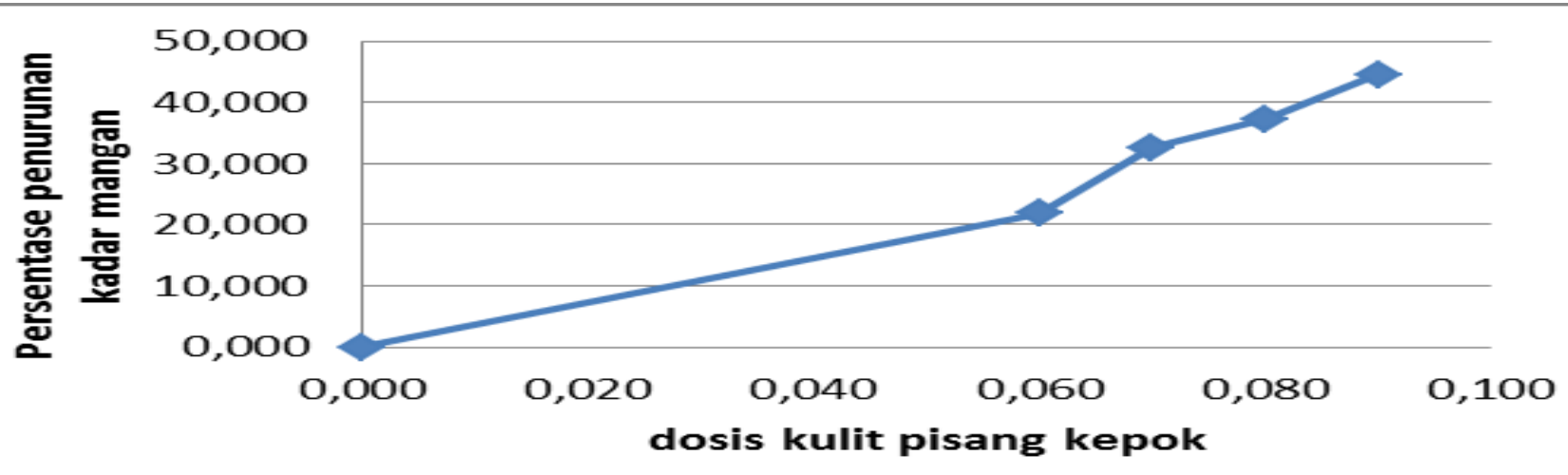

Gambar 4.4 Grafik Persentase antarberat kulit pisang terhadap penurunan kadar mangan

Dari grafik 4.4 secara kumulatif persentase penurunan kadar mangan dari hasil penambahan kulit pisang kepok dengan dosis 0 gram, 0,06 gram, 0,07 gram,0,08 gram, 0,09 gram, dan 0,1 gram adalah sebesar $0 \%, 21,845 \%$,

\section{Uji Statistik}

Uji Normalitas didapatkan hasil bahwa data tidak berdistribusi normal dengan nilai signifikan sebesar 0,020. Nilai tersebut kurang dari alpha 0,05 sehingga perlu dilakukan transformasi untuk mendapatkan distribusi normal. Dari hasil uji distribusi normal setelah transformasi dengan menggunakan log 10 didapatkan nilai signifikan sebesar 0,126 yang berarti nilai tersebut lebih besar dari nilai signifikan yang telah ditetapkan yaitu $\alpha=0,05$, sehingga dapat disimpulkan bahwa data berdistribusi normal.

Uji ANOVA dapat dilihat pada tabel 4.3, didapatkan nilai $p$ (di kolom Sig.) sebesar
$32,637 \%, 37,337 \%, 44,560 \%$, dan 52,916\%. Jadi penurunan kadar mangan paling besar dengan penambahan kulit pisang kepok dengan dosis 0,1 gram mencapai $52,916 \%$.

0,000 dimana < a 0,05 sehingga model regresi sederhana cocok (fit) dengan data yang ada.

Uji Regresi Linier melihat adanya pengaruh penambahan kulit pisang kepok terhadap penurunan kadar mangan pada air sumur dapat dilakukan uji statistik dengan menggunakan uji regresi linier menghasilkan nilai $p=0,000$ yang kurang dari alpha 0,05 sehingga menolak hipotesis nol (Ho) yang berarti ada pengaruh antara dosis kulit pisang kepok terhadap penurunan kadar mangan dalam air sumur. Selain itu, pada uji regresi linier didapatkan persamaan $Y=-0,060 x+0,094$ dan $R^{2}=0,967$. Pada nilai $R$ square diperoleh hasil 
yang mendekati angka 1 sehingga model regresinya semakin baik dan terdapat hubungan linier antara berat kulit pisang kepok (variabel bebas) terhadap kadar mangan (variabel terikat) pada air sumur.

Untuk melihat seberapa besar berpengaruhnya dosis kulit pisang kepok terhadap penurunan kadar mangan pada air sumur dilakukan uji koefisien determinasi. Koefisien determinasi digunakan unutk mengetahui persentase pengaruh variable bebas terhadap perubahan variable terikat. Berikut ini adalah tabel $R$ square (koefisien determinasi) yang merupakan hasil dari pengujian terhadap penurunan kadar mangan.

Berdasarkan pengujian tersebut didapatkan nilai persentase $\mathrm{R}^{2}$ (koefisien determinasi) sebesar 0,967 berarti pengaruh dosis kulit pisang kepok terhadap penurunan kadar mangan pada air sumur sebesar $96,7 \%$.

Mangan masuk ke dalam air oleh karena reaksi biologis pada kondisi reduksi atau anaerobik (tanpa oksigen). Jika air yang mengandung mangan dibiarkan terkena udara atau oksigen maka reaksi oksidasi besi atau mangan akan timbul dengan lambat dan membentuk endapan atau gumpalan koloid dari oksida besi atau oksida mangan yang tidak diharapkan. Endapan koloid ini akan menempel atau tertinggal dalam sistem perpipaan, menyebabkan noda pada cucian pakaian, serta dapat menyebabkan masalah pada sistem pipa distribusi disebabkan karena dapat menyokong tumbuhnya mikroorganisme seperti crenothrix dan clonothrix yang dapat menyumbat perpipaan serta dapat menimbulkan warna dan bau yang tidak enak (Hartini, 2012). Berdasarkan Keputusan Menteri Kesehatan No.416 Tahun 1990 menetapkan kadar zat mangan dalam air bersih yang diperbolehkan maksimum 0,5 mg/L.

Berdasarkan data hasil penelitian kadar mangan pada sampel air sumur terjadi penurunan kadar mangan (Mn) dengan membandingkan konsentrasi awal sebelum ditambahkan kulit pisang kepok kadar mangan adalah sebesar 1,149 ppm. Penjerapan mangan (Mn) paling besar terjadi pada konsentrasi $0,1 \%$. Secara kumulatif persentase penurunan kadar mangan dengan penambahan kulit pisang kepok adalah 0\%, 21,845\%, $32,637 \%$, 37,337\%, 44,560\%, dan 52,916\%. Penjerapan mangan (Mn) paling besar terjadi pada dosis 0,1 gram kadar mangan (Mn) mengalami penurunan menjadi 0,541 ppm dengan persentase penurunan mencapai $52,916 \%$.

Pada penurunan kadar mangan dalam air sumur, kulit pisang kepok berperan sebagai adsorben yang akan menjerap logamlogam berat dengan penjerapan ion-ion bebas yang ada dalam air termasuk mangan. Proses kerja penjerapan (adsorpsi) yaitu penjerapan ion-ion bebas di dalam air yang dilakukan oleh adsorben. Kandungan di dalam kulit pisang yang berfungsi sebagai adsorben adalah polisakarida. Polisakarida sendiri merupakan komponen terbesar dalam kulit pisang yang terdiri dari amilosa, amilopektin, dan selulosa.

Amilosa merupakan polisakarida yang terdiri dari polimer rantai lurus yang dibangun oleh ikatan $\alpha-(1,4)$-glikosidik dan pada setiap rantai terdiri dari 500 unit D-glukosa hingga 2000 unit D-glukosa.

Amilopektin adalah polisakarida terdiri dari polimer berantai cabang dengan ikatan $\alpha-$ $(1,4)$-glikosidik dan ikatan $\alpha$-(1,6)-glikosidik di tempat percabangannya. Setiap cabang terdiri dari 25 unit hingga 30 unit D-glukosa. Turunan dari pektin yang juga dapat mengikat kuat ion logam yang merupakan gugus fungsi gula karboksil adalah asam galakturonik (Suhartini 2012).

Selulosa merupakan polisakarida yang terdiri dari $\beta 1,4$ poli glukosa, dengan berat molekul sangat besar. Unit ulangan dari polimer selulosa terikat melalui ikatan glikosida yang mengakibatkan struktur selulosa linier.

Kemampuan selulosa, amilosa, maupun amilopektin untuk mengadakan interaksi dengan ion logam disebabkan senyawa tersebut mengandung gugus fungsional yaitu gugus hidroksil dan asam karboksilat.

Prinsip dasar dalam mekanisme pengikatan antara polisakarida dan logam berat yang terkandung dalam air adalah prinsip penukaran ion gugus hidroksil dan asam karboksilat khususnya gugus hidroksil dalam polisakarida akan bereaksi dan mengikat logam.

Logam mangan $(\mathrm{Mn})$ diikat oleh polisakarida dengan mentransfer proton $\mathrm{H}^{+}$dari gugus $-\mathrm{OH}$ ke dalam air, sehingga ion logam 
$\mathrm{Mn}^{2+}$ dapat menggantikan kedudukan proton $\mathrm{H}^{+}$dengan pembentukan kompleks kelat antara ligan-ligan - $\mathrm{OH}$ dengan atom pusat ion logam $\mathrm{Mn}^{2+}$.

Adanya gugus $-\mathrm{OH}$ menyebabkan terjadinya sifat polar pada adsorben kulit pisang kepok. Dengan demikian polisakarida lebih kuat menjerap zat yang bersifat polar dibandingkan zat yang kurang polar. Mekanisme adsorpsi yang terjadi antara gugus $-\mathrm{OH}$ yang terikat pada permukaan ion logam berat yang bermuatan positif merupakan mekanisme pertukaran ion. Interaksi antara gugus - $\mathrm{OH}$ dengan ion logam dimungkinkan melalui mekanisme pembentukan kompleks koordinasi karena atom oksigen pada gugus - $\mathrm{OH}$ mempunyai pasangan elektron bebas. Ion-ion $\mathrm{Mn}^{2+}$ akan berinteraksi kuat dengan anion yang bersifat basa kuat seperti $-\mathrm{OH}$. Ikatan antara ion $\mathrm{Mn}^{2+}$ dengan $-\mathrm{OH}$ pada polisakarida melalui pembentukan ikatan koordinasi, dimana pasangan elektron bebas dari $\mathrm{O}$ pada $\mathrm{OH}$ akan berikatan dengan ion logam $\mathrm{Mn}^{2+}$ membentuk ikatan kompleks melalui ikatan kovalen.

Sehingga dapat disimpulkan semakin besar penambahan kulit pisang ke dalam sampel air sumur maka persentase penurunan kadar mangan dalam air akan semakin tinggi.

\section{KESIMPULAN}

Ada hubungan linier antara berat kulit pisang kepok dengan kadar mangan dilihat dari persamaan regresi $Y=-0,060 x+0,094$ dan $R^{2}=0,967$. Sehingga dapat disimpulkan bahwa semakin meningkat dosis kulit pisang kepok maka semakin menurun kadar mangan dalam air sumur.

Ada pengaruh berat kulit pisang kepok terhadap penurunan kadar mangan pada air sumur dilihat dari analisa statistik dengan uji
Regresi Linier dengan a 0,05 dan tingkat kepercayaan $95 \%$ didapat nilai signifikasi 0,000 dan koefisien determinasi sebesar $96,7 \%$.

\section{DAFTAR PUSTAKA}

Aryani D., (2013). Efektivitas Kulit Pisang Kepok (Musa acuminate) terhadap Penurunan $\mathrm{Fe}^{2+}$ dalam Air, Universitas Muhamaddiyah Semarang

Castro, (2011). Southern Sui: a Fourth Sui Dialect. Journal of the Southeast Asian Linguistics Society

Cavalcante,J.S.,Costa,M.S.,Santee,U.R., Britto, L.R., (2005). Retinal Projections to the midline and intralaminar thalamic nuclei in the common marmoset (Callithrix jacchus).Brain Res.1043,42-47

Effendi, H., (2003), Telaah Kualitas Air Bagi Pengelolaan Sumber Daya Dan Lingkungan Perairan. Yogyakarta : Kanisius

Hartini, E., (2012). Efektivitas cascade aerator dan bubble aerator dalam menurunkan kadar mangan air sumur gali, Jurnal Kesehatan Masyarakat Universitas Negeri Semarang, vol 8, no. 1 hal 45

Maryse Bouchard, CINBIOSE, (2010). Intellectual Impairment in School-Age Children Exposed to Manganese from Drinking Water. UQAM

Purwanto, dan Syamsul H. (2005). Teknologi Industri Elektroplating, Semarang: Universitas Diponegoro

Suhartini. (2008). Pengaruh Keberadaan Tempat Pembuangan Akhir (TPA) Sampah Piyungan terhadap Kualitas Air Sumur Penduduk di Sekitarnya. Naskah Jurnal

Suprapti. Lies, (2005), Tepung Tapioka, Yogyakarta : Kanisius

Widowati, W., Sastiono, A., \& Jusuf R.R, (2008). Efek Toksik Logam. Yogyakarta: Andi 